\title{
Isolation and efficacy of native chitinolytic rhizobacteria for biocontrol activities against Fusarium wilt and plant growth promotion in pigeon pea (Cajanus cajan L.)
}

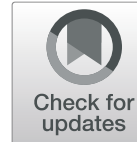

Ajinath Dukare ${ }^{1 *}$, Sangeeta Paul ${ }^{2}$ and Asha Arambam²

\begin{abstract}
The present study aimed to identify, characterize, and evaluate native chitinolytic rhizobacteria as biocontrol potential against pigeon pea wilt disease, caused by Fusarium udum. A total of 53 isolated rhizobacteria was evaluated for their chitinolytic potential and possession of different antifungal traits. From the successive in vitro experiments and in vivo bioassay, 2 promising bacterial strains (NS-1 and NS-22) that exhibited strong chitinolytic activities and mycolytic action were biochemically characterized and identified as Pseudomonas spp. NS-1 (NCBI GenBank accession number- KT175909) and Bacillus spp. NS-22 (NCBI GenBank accession number-MH425454), using $16 \mathrm{~S}$ rDNA sequencing. In planta, disease severities for Pseudomonas spp. NS-1- and Bacillus spp. NS-22-treated plants were only about 14.62 and 23.08\%, respectively, as compared to pathogen-only control (67.34\%) at the end of 4 weeks. Additionally, these bacteria improved plant germination and fresh and dry plant biomasses under pathogenchallenged conditions. Further, both the strains were able to cause a considerable amount of reduction in the fungal biomass, as revealed by bacteria-pathogen interaction studies in liquid culture. Scanning electron microscopy studies also revealed the strong antifungal activities of these 2 chitinolytic bacteria on the pathogen hyphae and mycelia. The curling, bulging, breakdown, and other dysfunctionalities in fungal hyphae were induced by the biocontrol bacteria. In nutshell, the present exclusive investigation demonstrated mycolytic potential and biocontrol prospects of the 2 promising bacteria (Pseudomonas spp. NS-1 and Bacillus spp. NS-22) for the sustainable Fusarium wilt management and as a phytostimulator in pigeon pea.
\end{abstract}

Keywords: Chitinolytic bacteria, Fusarium udum, Antifungal potential, Biological disease Suppression, Fungal biomass reduction

\section{Background}

Soil-borne fungal pathogens such as Fusarium udum, Pythium sp., Phytophthora sp., Rhizoctonia spp., cause severe plant diseases, hamper crops yield, and also damage produce quality (Morrissey et al. 2004). Such fungal pathogens with a broad host range resulting into diseases of many economically agricultural crops. Traditionally, synthetic

\footnotetext{
* Correspondence: ajinath111@gmail.com

'Division of Horticultural Crop Processing, Indian Council of Agricultural Research (ICAR) - Central Institute of Post-Harvest Engineering \& Technology (CIPHET), Abohar, Punjab 152116, India

Full list of author information is available at the end of the article
}

fungicides such as bavistin, benomyl, and thiram are mainly used to control the incidence of Fusarium and other soil pathogenic fungi (Melent'ev et al. 2006). However, excessive fungicide usage results in ecosystem pollution, effects on non-target microorganisms, pathogen's resistance towards fungicides, and health risks to human (Dukare et al. 2019). Consequently, alternate approaches are required for their eco-friendly and sustainable management.

Biological control of diseases, using antagonistic microbiota, promotes sustainable agriculture due to their non-polluting and eco-safe nature (Dukare et al. 2020). 
Recently, biocontrol has paid attention on the use of mycolytic enzymes producing plant growth promoting microbes. Further, the rhizospheric microbe's application for managing crops biotic and abiotic stresses has been well documented (Sangwan and Dukare 2018). So far, numerous bacterial species from genera comprising Bacillus, Paenibacillus, Pseudomonas, Azotobacter, Streptomyces, and Lysobacter have been reported as phytostimulator, biofertilizers, and biocontrol agents (Naing et al. 2015). Their biocontrol capacity is due to mycoparasitism via lytic enzyme, antibiotic secretion, competitive exclusion of nutrients and space, formation of biofilm and reactive oxygen species, and induced host defense (Saraf et al. 2014).

Chitin ( $\beta-1,4$-glycosidic bonds linked linear polymer of $\mathrm{N}$-acetylglucosamine), an important and most abundant structural polysaccharide in fungal cell wall, gives cell wall integrity and cellular strength (Anees et al. 2019). Hence, the cell wall degrading enzymes of microbial antagonists contributes to theirs biocontrol potential. Chitin degradation is one of the chief mechanisms of biocontrol involved in the microbe mediated pathogen suppression (Manjula and Podile 2005). Mycolytic enzymes (chitinases and glucanase) break down chitin into deacylated oligomer chitosan, monomer $\mathrm{N}$-acetylglucosamine, and the disaccharide chitobiose. This enzymatic action brings structural and cellular disintegration, lysis, and subsequent fungal death (El-Tarabily 2006). Further, other antifungal metabolites such as certain antibiotics, inhibitory substances (Hydrogen cyanide) and volatile /diffusible metabolites, and siderophores also prevents pathogen proliferation via spore and conidial germination inhibition. Due to their mycolytic activities, chitinaseproducing bacteria prevents the proliferation of phytopathogens and holds great potential in regard to their development as biofungicides. Biocontrol ability of such bacteria has been reported against many crop pathogens (Berini et al. 2018). For example, biocontrol attributes of bacteria, Pseudomonas spp. GRC3 against root rot fungal diseases are correlated with chitinase production (Lee et al. 2009).

India is the major pigeon pea-growing nation with almost $90 \%$ in global acreage and production (FAOSTAT 2013). The wilt disease caused by $F$. udum is a major biotic stress, which adversely affects crop growth and yield. Up to 30 to $60 \%$ disease incidences may occur during flowering and crop maturity (Sharma et al. 2016). Under such a situation, sustainable wilt management is crucial in order to minimize negative side effects of agrochemicals. The present study was directed towards isolation and evaluating the bio-protection ability of most promising chitin-degrading rhizobacteria, targeting cell wall of $F$. udum pathogen during in vitro and in vivo studies.

\section{Materials and methods}

\section{Isolation of chitin-degrading bacteria (CDB)}

Soil samples were collected from the rhizosphere of vegetative stage of pigeon pea crop on the experimental field of the Genetics Department, ICAR-Indian Agricultural Research Institute, New Delhi, India. Ten healthy plants were selected at random, carefully uprooted, and then loose adhered soil to primary and secondary roots (depth of $15 \mathrm{~cm}$ ) was collected in a clean aseptic polythene bag and brought to the laboratory for further processing. Colloidal chitin (CC) was prepared using the crab shell chitin powder (Sigma Chemicals Company, USA) as per the modified method of Mathivanan (1995). In order to obtain the maximum number of $\mathrm{CDB}$, isolation was carried out by serial dilutions and soil enrichment technique (El-Tarabily et al. 2000), using 0.4\% CC as sole carbon source. Following incubation, morphologically different bacterial colonies were picked, purified, and maintained on nutrient agar (NA) media.

\section{Growth and maintenance of $F$. udum}

The virulent strain of $F$. udum, responsible for wilt disease in pigeon pea, was obtained from Indian Type Culture Collection (ITCC), Division of Plant Pathology, ICAR-IARI, New Delhi, India. Pathogen inoculum was multiplied in potato dextrose broth (PDB). Viability and pathogenicity of culture were preserved by regular sub culturing on potato dextrose agar (PDA).

\section{Screening of bacterial isolates for chitinolytic ability Qualitative assay}

Qualitative assay for chitin utilization by selected bacterial isolates was performed by $1 \%$ colloidal chitin agar (CCA) supplemented with fluorescent dye Calcofluor white M2R (Vaidya et al. 2003). Actively growing 24-h bacterial culture in Luria Bertani (LB) broth was spot inoculated in the center of 1\% CCA plate and incubated at $28^{\circ} \mathrm{C}$ for $48-72 \mathrm{~h}$. After incubation, a clear chitin hydrolysis halos $(\mathrm{mm})$ formed around the bacterial colonies were measured and promising $\mathrm{CDB}$ were chosen further based on the size of chitin-degrading zones in media. The experiment was conducted with 3 replications and repeated twice.

\section{Quantitative assay}

Chitinase activities in the chosen 13 best isolated CDB were quantified as per the method of Aggarwal et al. (2017). Five milliliter LB broth (containing $0.4 \%$ CC) was inoculated with the $1 \% \mathrm{v} / \mathrm{v}$ of actively growing 24 -h-old bacterial culture and incubated on a rotary shaker (150 $\mathrm{rpm})$ at $28^{\circ} \mathrm{C}$ for $72 \mathrm{~h}$. Subsequently, the broth was centrifuged ( $8000 \mathrm{rpm}$ for $5 \mathrm{~min}$ ) and the supernatant was used as crude extract for chitinase enzyme assay. Simultaneously, protein content in pellet was estimated as per 
the method of Lowry et al. (1951). One unit of chitinase activity was defined as the amount of enzyme which produced $1 \mathrm{~mol}$ of amino sugars as glucosamine per minute. The experiment was repeated twice with three replications each time.

\section{In vitro assay for antifungal activity}

Antagonistic activities of chitinolytic bacteria were evaluated on PDA plates, using dual culture technique (Vincent 1947). In this assay, mycelial disk $\left(5-\mathrm{mm}^{2}\right.$ disk) of actively growing $F$. udum culture was centrally placed on PDA plate. A 24-h-old bacterial culture was circularly streaked ( $3.5 \mathrm{~cm}$ apart) surrounding the fungal inoculum disk. Petri plates were incubated at $28 \pm 2{ }^{\circ} \mathrm{C}$ for $72-96$ $\mathrm{h}$ and pathogen growth (in diameter, $\mathrm{mm}$ ) was measured and compared to control (where the bacterial suspension was replaced with sterilized LB medium). The experiment was repeated twice with 3 replications each time. Fungal growth inhibition (\%) in the presence of bacterial isolates was calculated using the following formula:

Fungal growth inhibition $(\%)=(\mathrm{C}-\mathrm{T}) / \mathrm{C} \times 100$ where $\mathrm{C}=$ mycelia growth of fungi in control and $\mathrm{T}=$ mycelia growth of fungi in treatment

\section{Greenhouse bioassay}

Five best isolates (P-2, P-16, NS-1, NS-2, and NS-22) in terms of possessing strong chitinolytic activity and pathogen suppression potential in vitro were evaluated for their bio-protection ability under greenhouse conditions. The healthy, uniform, and defects free seeds of wilt susceptible pigeon pea variety (Pusa-200) were obtained from the Genetics Department, ICAR-IARI, New Delhi. Seeds were sterilized by soaking them in $0.1 \%$ $\mathrm{HgCl}_{2}$ for $3 \mathrm{~min}$ and rinsed 3 times with sterile distilled water (SDW). These sterilized seeds were immersed in cell suspension (under aseptic conditions for $2 \mathrm{~h}$ ) of selected bacteria and used for sowing in the pots. The biocontrol efficacy was assessed in pathogen-challenged pigeon pea seedlings under the greenhouse conditions of the Microbiology Division. The pathogen inoculums containing $2 \times 10^{8}$ spores $\mathrm{ml}^{-1}$ was mixed into potting medium at $150 \mathrm{ml} \mathrm{kg}^{-1}$ of soil and incubated as such for 5-7 days in order achieve proper for spore germination and establishment of pathogen mycelium (Pandey and Dubey 1994). After that time, surface-sterilized seeds were sown in each pot (4 seeds pot ${ }^{-1}$ ) and daily observations were taken for germination and wilt incidence. Each treatment had 5 replications. Treatment details of the pot bioassay under greenhouse conditions included $\mathrm{T}-1$, un-inoculated control (without pathogen and bacteria); T-2, F. udum + recommended chemical treatment; T-3, F. udum only; T-4, F. udum + CDB P-2; T-5, F. udum + CDB P-16; T-6, F. udum + CDB NS-1; T-7, F. udum + CDB NS-2; and T-8, F. udum + CDB NS-22.
For treatments $\mathrm{T}-4, \mathrm{~T}-5, \mathrm{~T}-6, \mathrm{~T}-7$, and $\mathrm{T}-8$, seeds were bacterized with $24 \mathrm{~h}$ grown cultures $\left(\mathrm{OD}_{600}=1\right.$, corre-

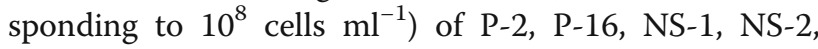
and NS-22 CDB isolates, respectively. Except for uninoculated control ( $\mathrm{T}-1$ seeds treated with SDW were used), potting medium in all other treatments was preinoculated with the $F$. udum spores. Seeds treated with thiram (at $4 \mathrm{~g} \mathrm{~kg}^{-1}$ ) of seed were used as the recommended chemical treatment.

Observations on the number of seeds germinated and surviving (\%) were recorded from 7 days onwards of sowing. Post-emergence disease incidence (\%) was measured (Dukare et al. 2011). After 5 weeks, the seedlings were uprooted and rinsed gently under tap water to detach all adhering soil particles and observations on fresh shoot/roots weight $(\mathrm{g})$ were recorded in triplicate and analyzed. The experiment was repeated twice.

\section{Characterization and identification of biocontrol bacterial strains}

The two most efficient bacteria (NS-1 and NS-22) showed both excellent chitinase activity and antifungal potential against $F$. udum under laboratory and greenhouse trials were characterized and identified.

\section{Colony morphology based on biochemical characterization}

Morphology of colony characterization was done, using visual appearance of colony growth on the NA. Furthermore, isolated strains were also characterized based on selected biochemical parameters such as grams-staining, hydrogen sulfide $\left(\mathrm{H}_{2} \mathrm{~S}\right)$ production, catalase production, urease test, gelatinase assay, and citrate utilization test. Carbon utilization test was performed for carbohydrate fermentation, Triple sugar iron (TSI) utilization, methyl red, and Voges-Proskauer (VP) test. Biochemical characterization was carried out as per the manual of Cappuccino and Sherman (1992).

\section{$16 \mathrm{~S}$ ribosomal DNA sequencing}

Identification of the selected 2 best bacteria was further confirmed through the sequencing of $16 \mathrm{~S}$ rDNA. Genomic DNA was isolated from the chosen CDB using a Zymo g-DNA kit and was amplified using the universal bacterial primers 16a (50 AGAGTTTGATCCTGGCTC 30) and 16b (50 TACGGYTACCTTGTTACGACTT 30) by initial denaturation (at $94{ }^{\circ} \mathrm{C}$ for $2 \mathrm{~min}$ ), 30 cycles of denaturation (at $94{ }^{\circ} \mathrm{C}$ for $1 \mathrm{~min}$ ), annealing (at $56^{\circ} \mathrm{C}$ for $1 \mathrm{~min}$ ), extension (at $72^{\circ} \mathrm{C}$ for $1 \mathrm{~min} 30 \mathrm{sec}$.), and final extension (at $72{ }^{\circ} \mathrm{C}$ for $6 \mathrm{~min}$ ), using a Qcycler II thermal cycler (Aggarwal et al. 2015). The PCR products, purified using a Fermentas Gene JETTM PCR purification kit, were sent for sequencing in both directions to the Sci Genome Labs Pvt Ltd, Kerala (India). The DNA 
sequencing was performed using Sequencer ABI 3730Xl (Applied Biosciences). Using BLAST (Basic Local Alignment Search Tool) searches, the sequence was compared with known and identified strains in the National Center for Biotechnology Information (NCBI) database (http:// ncbi.nlm.nih.gov/blast) and then submitted to its GenBank.

\section{Effect of effective chitinolytic bacterial strains on biomass of $F$. udum}

The antagonistic effects of the selected 2 most antifungal efficient bacterial strains (NS-1 and NS-22) on the biomass of F. udum were assayed in liquid cultures according to the modified method (Harish et al. 1998). For this study, $100 \mathrm{ml}$ of conical flasks containing $25 \mathrm{ml}$ PD broth was inoculated simultaneously (co-inoculation) with selected bacteria (24-h-old culture) and F. udum (cell density of $2 \times 10^{8}$ spores $\mathrm{ml}^{-1}$ ). Control flask included PD broth inoculated with pathogen only. Following inoculation, flask was incubated at $30^{\circ} \mathrm{C}$ and dry weight of the pathogen mycelium was assessed after filtration through pre-weighed Whatman No. 1 filter paper. The dry weight (mg) of the fungal mycelium was observed at $24 \mathrm{~h}$ intervals up to $72 \mathrm{~h}$. The experiment was repeated twice with 3 replications each time.

\section{Scanning electron microscopy studies on biocontrol bacteria-pathogen interaction}

The investigation on effect of biocontrol bacteria on $F$. udum mycelia was also performed, using scanning electron microscopy (SEM). The pathogen mycelia were taken from inhibited zone interface (interactive zone between bacteria and hyphae of F. udum on PDA plate) area as treated samples and uninhibited part as control. Then mycelia were prefixed with $2 \%$ glutaraldehyde in $20 \mathrm{mM} \quad \mathrm{NaHPO}_{4}$ buffer (pH 6.5) plus 5\% dimethyl sulphoxide for $30 \mathrm{~min}$. After pre-fixation, the mycelia were gently washed with sterilized water, fixed with osmium tetraoxide dissolved in $50 \mathrm{mM} \mathrm{NaHPO}$ buffer (pH 6.5) and then slowly dehydrated in series of alcohol grades. Later, samples were mounted on SEM stubs using double-sided aluminum tapes and coated with gold palladium (15-18-nm thickness) in an ion sputter coater at high vacuum. Finally, high-resolution images were recorded by Zeiss EVOMA 10 SEM under pressure of $10 \mathrm{mbar} / \mathrm{pa}$ and 15-20 kv (Mandal et al. 2013).

\section{Statistical analysis}

The data was recorded in triplicate and analyzed, using the IBM SPSS software version 16.0. Analysis of variance was determined and the mean values were compared by Duncan's multiple range tests at $P<0.05$. Standard error of means (3 replications) values is depicted in the graphs as bars.

\section{Results and discussion}

Isolation of $\mathrm{CDB}$ from pigeon pea rhizosphere

A total of $53 \mathrm{CDB}$ was isolated from the pigeon pea rhizosphere. Among them, a total 26 bacterial isolates was obtained using serial dilutions method and remaining 27 were from the enrichment culture technique. Isolates differing in colony morphology and characteristic were picked, purified, and used in further stages of the experiment. The rhizosphere represents a major hotspot for the bacteria with chitin-degrading potential (Das et al. 2010). Usually, the extracellular chitinases of such bacteria allow efficient utilization of chitin present in surroundings as an energy source under both aerobic and anaerobic conditions. The presence of large proportions of chitinolytic bacteria in agricultural fields has demonstrated (Kuddus and Ahmad 2013).

\section{Chitinolytic activity of chitin-degrading bacterial isolates}

Chitinolytic activity of isolated bacteria was estimated on CCA plate (Fig. 1). As shown in Table 1, only 13 bacterial isolates among the total showed chitin hydrolysis zones ranging from 2.6 to $8.8 \mathrm{~mm}$, while all remaining (40 isolates) depicted negligible chitinolytic activity $(<$ $2.5 \mathrm{~mm})$. The highest zone $(8.80 \pm 0.10 \mathrm{~mm})$ was formed around colonies of CDB NS-17, followed by CDB NS-1 and CDB NS-22. The isolates that showed more than $2.5 \mathrm{~mm}$ of chitin hydrolysis zone were used in further studies. The data on quantification of chitinase activity in isolated strains are presented (Table 1). The highest chitinase activity $\left(798.35 \pm 30.45 \mathrm{U} \mathrm{mg}^{-1}\right.$ protein) was detected in CDB NS-22, followed by CDB NS-1, while the lowest chitinase activity was in CDB P-5. Enzyme activity in CDB NS-22 was non-significant with that obtained in CDB NS-1 isolate, though; it was significant when compared to remaining isolates.

Likewise, chitinases were effectively diffused through agar media, bioassay to identify bacteria producing such enzymes was carried out by examining the degradation of chitin polymer added into an agar medium (Howard et al. 2003). From in vitro, microbes with strong chitinolytic activities are usually selected based on the bigger and clearer chitin hydrolysis zones formed in CCA media (Vaidya et al. 2003). This is the most followed and reported approach for the initial screening and selection of potentially high chitinase-producing isolates (Aggarwal et al. 2015).

\section{In vitro antifungal activities of chitinolytic bacteria against $F$. udum}

Among the screened 13 best chitinolytic bacterial strains isolates for antifungal activities against F. udum, 11 isolates significantly reduced pathogen mycelia growth. As compared to the control, the lowest pathogen growth, i.e., $24.00 \pm 0.58 \mathrm{~mm}$ was observed in the presence of 


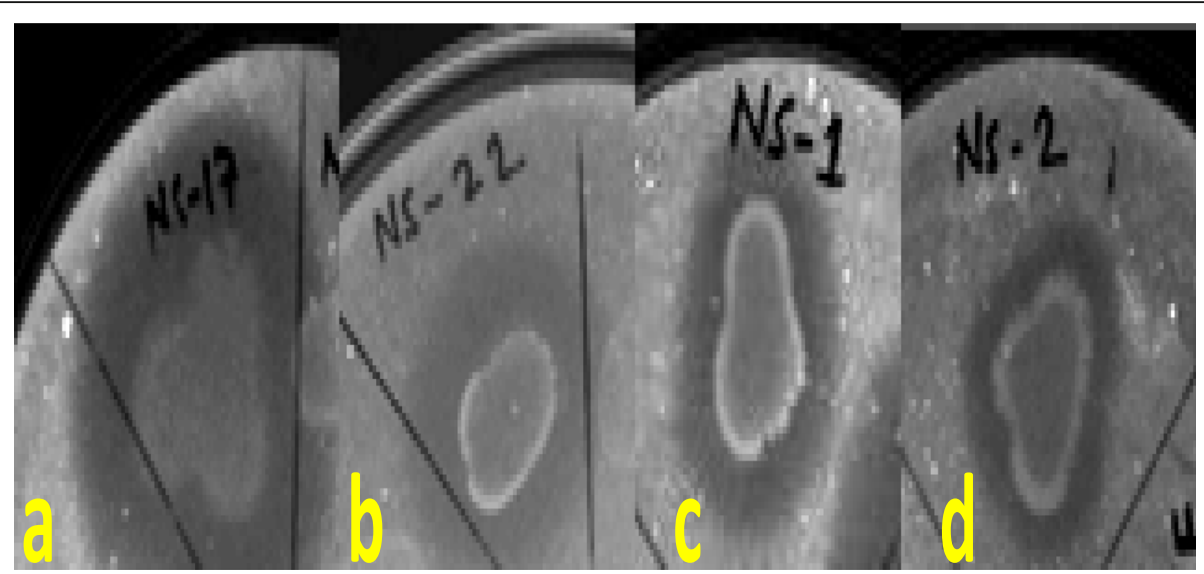

Fig. 1 Clear zone of chitin hydrolysis produced on 1\% CCA plate by the bacterial isolates obtained from pigeon pea rhizosphere. a Chitin hydrolysis zone formed by isolate NS-17. b Chitin hydrolysis zone formed by isolate NS-22. c Chitin hydrolysis zone formed by isolate NS-1. d Chitin hydrolysis zone formed by isolate NS-2 (representative images of few isolates)

CDB NS-22 (Table 2). In terms of fungal growth inhibition (\%), CDB NS-22 induced the highest growth inhibition (67.57\%), followed by CDB isolate NS-1 (62.16\%). Two chitin-degrading bacterial isolates, i.e., CDB P-5 and CDB P-10 did not exhibit any antagonism towards F. udum. Two best bacterial isolates, namely NS-1 and NS-22, demonstrated strong chitinase activities as well were highly biocidal against $F$. udum. Furthermore, a positive correlation $(r=0.89)$ was noticed between chitinase activity and pathogen growth inhibition in vitro.

From dual culture assay, the antifungal ability of isolates against $F$. udum was evident from the reduction in radial mycelial growth of pathogen (Table 2). The increased production of bacterial chitinases and their

Table 1 Zone of chitin hydrolysis and chitinase activity exhibited by the selected efficient rhizobacterial isolates

\begin{tabular}{lll}
\hline Bacterial isolates & $\begin{array}{l}\text { Size of clear halo around bacterial } \\
\text { colonies (diameter in mm) }\end{array}$ & $\begin{array}{l}\text { Chitinase activity } \\
\left(\mathrm{U} \mathrm{mg}^{-1} \text { protein) }\right.\end{array}$ \\
\hline P-2 & $2.60 \pm 0.05^{\mathrm{J}}$ & $483.67 \pm 23.80^{\mathrm{CD}}$ \\
P-3 & $4.05 \pm 0.02^{\mathrm{H}}$ & $406.33 \pm 24.12^{\mathrm{DE}}$ \\
P-5 & $4.50 \pm 0.00^{\mathrm{G}}$ & $284.09 \pm 16.81^{\mathrm{F}}$ \\
P-10 & $4.10 \pm 0.05^{\mathrm{H}}$ & $324.68 \pm 24.21^{\mathrm{EF}}$ \\
P-13 & $3.45 \pm 0.03^{1}$ & $447.67 \pm 49.78^{\mathrm{CD}}$ \\
P-14 & $4.05 \pm 0.02^{\mathrm{H}}$ & $397.56 \pm 36.76^{\mathrm{DE}}$ \\
P-16 & $6.35 \pm 0.07^{\mathrm{F}}$ & $497.17 \pm 15.21^{\mathrm{CD}}$ \\
P-17 & $7.85 \pm 0.07^{\mathrm{C}}$ & $441.66 \pm 5.78^{\mathrm{CD}}$ \\
P-18 & $7.50 \pm 0.00^{\mathrm{D}}$ & $485.22 \pm 5.87^{\mathrm{CD}}$ \\
NS-1 & $8.55 \pm 0.02^{\mathrm{A}}$ & $632.73 \pm 27.46^{\mathrm{B}}$ \\
NS-2 & $6.65 \pm 0.08^{\mathrm{E}}$ & $538.03 \pm 78.38^{\mathrm{BC}}$ \\
NS-17 & $8.80 \pm 0.10^{\mathrm{A}}$ & $542.45 \pm 20.76^{\mathrm{BC}}$ \\
NS-22 & $8.15 \pm 0.07^{\mathrm{B}}$ & $798.35 \pm 30.45^{\mathrm{A}}$ \\
\hline
\end{tabular}

Note: Values following with the same letter are not significantly different according to DMRT test at $P \leq 0.05$ corresponding role in curbing the growth, development, and virulence of pathogen via hindering fungal spores' germination, and germ-tube elongation and finally, destroying pathogen oospores are reported (Dukare et al. 2019). Overall, biological pathogen inhibition through enzymatic disintegration of fungal cell walls has been one of the prime biocontrol mechanisms of certain species of Bacillus and Pseudomonas. The in vitro reduction in radial mycelia growth of Fusarium solani was caused by Bacillus subtilis (Sarhan et al. 2001). Similar to Bacillus species, many strains of Pseudomonas produces cyclic lipopeptide as well as mycolytic enzymes

Table 2 In vitro antagonistic activities of the promising chitinolytic bacterial isolates against pigeon pea wilt pathogen (Fusarium udum)

\begin{tabular}{lll}
\hline $\begin{array}{l}\text { Chitinolytic } \\
\text { bacterial strains }\end{array}$ & $\begin{array}{l}\text { Growth of } F \text {. udum } \\
\text { (diameter in mm) }\end{array}$ & $\begin{array}{l}\text { Pathogen growth } \\
\text { inhibition (\%) }\end{array}$ \\
\hline Control (pathogen only) & $74.00 \pm 1.15^{\mathrm{I}}$ & - \\
P-2 & $38.00 \pm 1.15^{\mathrm{F}}$ & 48.65 \\
P-3 & $68.66 \pm 0.88^{\mathrm{A}}$ & 7.21 \\
P-5 & $74.00 \pm 0.58^{\mathrm{l}}$ & 0.00 \\
P-10 & $74.00 \pm 0.00^{\mathrm{I}}$ & 0.00 \\
P-13 & $60.00 \pm 1.15^{\mathrm{B}}$ & 18.92 \\
P-14 & $56.00 \pm 1.53^{\mathrm{C}}$ & 24.32 \\
P-16 & $39.00 \pm 0.58^{\mathrm{F}}$ & 47.30 \\
P-17 & $46.33 \pm 0.67^{\mathrm{D}}$ & 37.39 \\
P-18 & $53.33 \pm 0.88^{\mathrm{C}}$ & 27.93 \\
NS-1 & $28.00 \pm 0.58^{\mathrm{G}}$ & 62.16 \\
NS-2 & $37.00 \pm 1.53^{\mathrm{F}}$ & 50.00 \\
NS-17 & $49.67 \pm 1.20^{\mathrm{D}}$ & 32.88 \\
NS-22 & $24.00 \pm 0.58^{\mathrm{H}}$ & 67.57 \\
\hline
\end{tabular}

Note: Values following with the same letter are not significantly different according to DMRT test at $P \leq 0.05$ 
(chitinase, endo and exo chitinase, cellulase, protease, and lipase) that are inhibitory to pathogens growth (AlFadhal et al. 2019).

\section{In vivo bioassay of promising chitinolytic and antifungal bacterial strains against $F$. udum}

Five of the most effectual CDB (P-2, P-16, NS-1, NS-2 and NS-22) that showed strong chitinolytic activity and pathogen suppression potential during in vitro trials were evaluated for their bio-protection abilities under greenhouse conditions.

\section{Effect of seed inoculation with CDB on Fusarium wilt} incidence (\%) and seed germination (\%) in pigeon pea The information pertaining to the Fusarium wilt incidence (\%) as affected by seed inoculation of CDB isolates are presented (Fig. 2). The highest wilt incidence $(67.34 \%)$ was observed in the pathogen-only inoculated treatment (T-3), followed by CDB P-2-treated (T-4) plants (65.41\%) (Fig. 2). However, both these treatments were non-significant. CDB NS-1 inoculated plants in T-6 treatment showed significantly the lowest disease occurrence (14.62\%), followed by the CDB NS-22-treated plants (23.07\%). Absolute control treatment (T-1), without any pathogen pre-challenge, did not show any wilt incidence. As shown in Fig. 3, the highest seed germination (93.33\%) was observed in the treatment T-6 (seed bacterized with CDB NS-1), followed by treatments T-8 (seed inoculated with CDB NS-22) and T-1 (absolute control), both having similar $(86.67 \%)$ seed germination. The lowest seed germination was recorded in the treatment, T-3 (Only F. udum challenged pots). As compared to other treatments, germination (\%) in T-3 treatment was significantly lower, while it was significant high in T-6 treatment than $\mathrm{T}-3, \mathrm{~T}-4$, and $\mathrm{T}-5$ treatments.

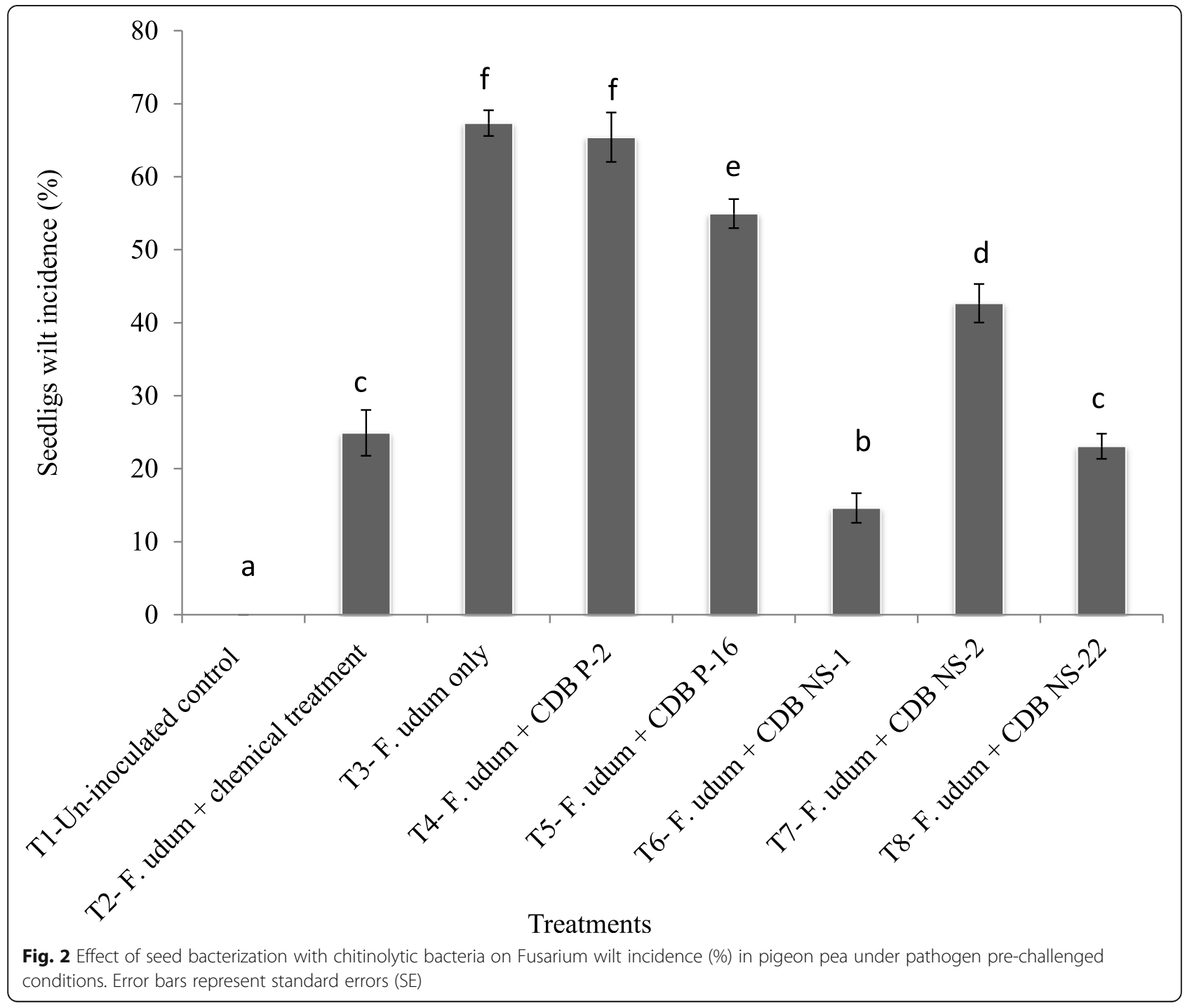




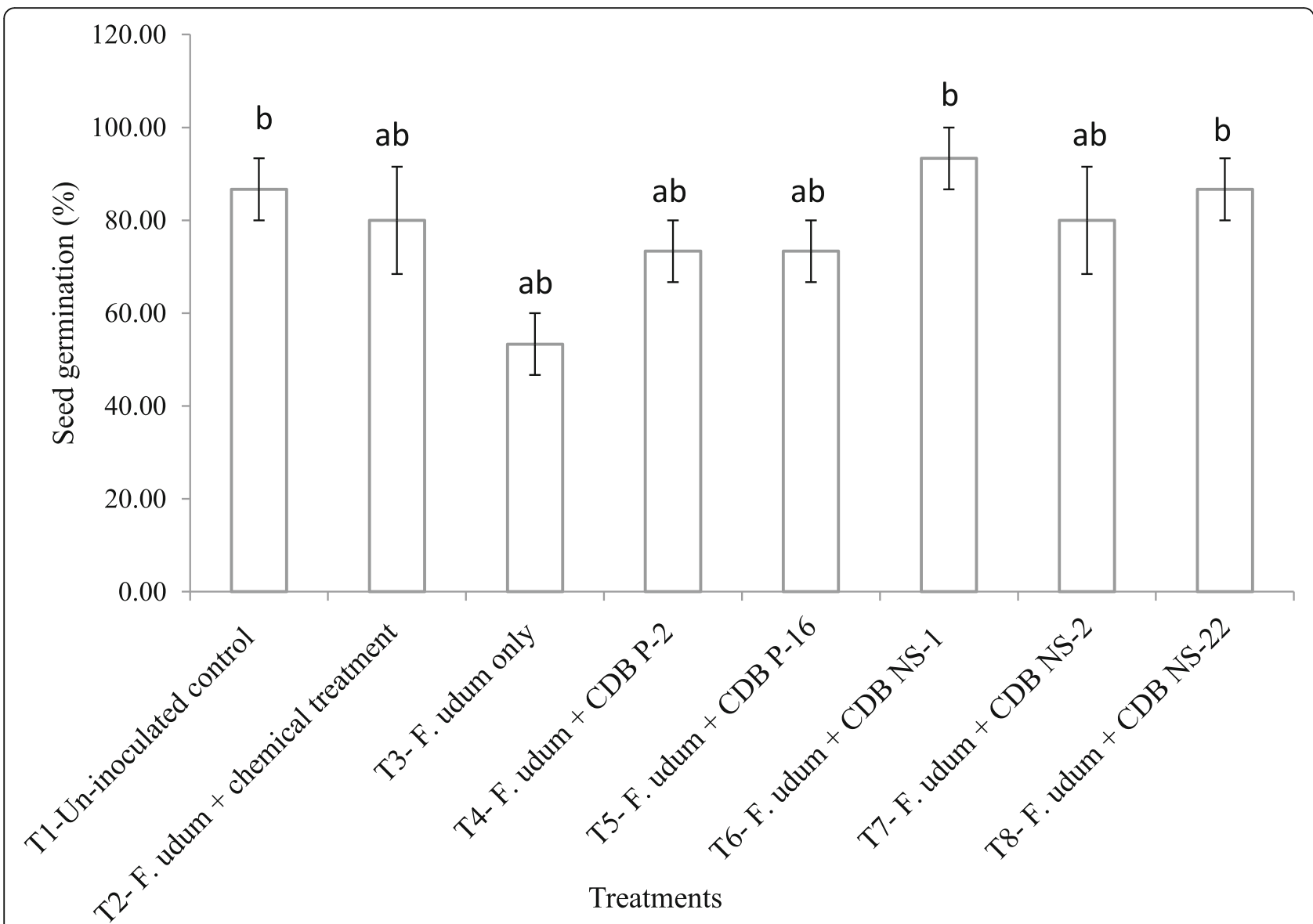

Fig. 3 Effect of seed bacterization with chitinolytic bacteria on germination (\%) of pigeon pea under F. udum pre-challenged conditions. Values are mean of three replications \pm standard errors (SE)

In planta bioassay, seed inoculation with promising chitinolytic bacteria suppressed pathogen growth, lessened wilt disease incidence and at the same time, improved seed germination and plant biomass. In the study of Dukare and Paul (2018), the 2 bacteria (Pseudomonas spp. NS-1 and Bacillus spp. NS-22) reduced considerably the Fusarium propagules in crop rhizosphere and controlled wilt disease incidence. Bacillus spp. and Pseudomonas spp. are the most ubiquitous soil bacteria that serve as phytostimulator and bio-protector in crop rhizosphere. Their antifungal metabolites are known to suppress many soilborne phytopathogens such as Rhizctonia solani and $F$. solani (Al-Fadhal et al. 2019). Certain species of genera Bacillus and Pseudomonas curb crops harmful fungal growth by extracellular production of antibiotics, biosurfactants, lytic enzymes, siderophores, host defense induction, survival under stress, and effective rhizosphere colonization under both greenhouse and field conditions (Radhakrishnan et al. 2017). These findings are in harmony with the observations that artificial inoculation of chitinolytic bacteria suppresses pathogen development under natural environment (Idris et al. 2007).

\section{Effect of seed inoculation on fresh and dry shoots and root biomass of pigeon pea seedlings}

The data pertaining to the fresh shoot and root biomass as influenced by the seed application of effective CDB are presented in Table 3. Among the treatments, the highest fresh shoot biomass $(1507.00 \pm 51.39 \mathrm{mg})$ was observed in T-8 treatment, followed by T-6 treatment $(1407.66 \pm 42.35 \mathrm{mg})$. The significant lowest shoot weight was observed in T-5 $(758.33 \pm 13.69 \mathrm{mg})$ treatment. Shoot biomasses recorded in T-5, T-4, and T-3 treatments were non-significant. In terms of percentage, plants grown with CDB NS-1 and CDB NS-22 isolatetreated seeds caused 70.28 and $82.30 \%$ increases in shoot biomass, respectively, over pathogen control treatment (T-3). Similar to fresh shoot weight, the highest root biomass $(242.66 \pm 13.93 \mathrm{mg})$ was measured in CDB NS-22treated plants (T-8), followed by CDB NS-1 inoculated plants ( $\mathrm{T}-6)$. Root biomass value in ' $\mathrm{T}-8$ treatment was significantly higher than other treatments. The lowest $(96.66 \pm 6.96 \mathrm{mg})$ root biomass was observed in pathogen-alone treatment (T-3). Plants treated with CDB NS-1 and NS-22 showed 113.45 and 151.03\% 
Table 3 Effect of seed inoculation with efficient chitinolytic bacteria on fresh biomasses of pigeon pea plants under pathogen prechallenged conditions

\begin{tabular}{|c|c|c|c|c|}
\hline \multirow[t]{2}{*}{ Treatments } & \multicolumn{4}{|c|}{ Fresh plant biomasses (mg) } \\
\hline & Shoot biomasses & $\%$ change over pathogen control & Root biomasses & $\%$ change over pathogen control \\
\hline$\overline{\mathrm{T}-1}$ & $1023.66 \pm 37.69^{B C}$ & 24.63 & $136.66 \pm 10.83^{C D}$ & 41.38 \\
\hline $\mathrm{T}-2$ & $1256.33 \pm 12.33^{\mathrm{AB}}$ & 52.96 & $183.66 \pm 9.61^{B}$ & 90 \\
\hline $\mathrm{T}-3$ & $821.33 \pm 36.19^{c}$ & 0.00 & $96.66 \pm 6.96^{\mathrm{D}}$ & 0.00 \\
\hline $\mathrm{T}-4$ & $811.33 \pm 24.74^{C}$ & -1.22 & $115.66 \pm 8.76^{\mathrm{CD}}$ & 19.66 \\
\hline $\mathrm{T}-5$ & $758.33 \pm 13.69^{C}$ & -7.67 & $103.66 \pm 9.93^{\mathrm{CD}}$ & 7.24 \\
\hline T-6 & $1407.66 \pm 42.35^{A}$ & 71.39 & $206.33 \pm 9.38^{\mathrm{AB}}$ & 113.45 \\
\hline $\mathrm{T}-7$ & $910.00 \pm 17.77^{B C}$ & 10.80 & $143.00 \pm 5.85^{c}$ & 47.93 \\
\hline $\mathrm{T}-8$ & $1507.00 \pm 51.39^{A}$ & 83.48 & $242.66 \pm 13.93^{\mathrm{A}}$ & 151.03 \\
\hline
\end{tabular}

Note: Values following with the same letter are not significantly different according to DMRT test at $P \leq 0.05$

increases in root biomass, respectively, over pathogenonly control (T-3). Fungicide-treated plants showed 92.65\% increase in root biomass over $\mathrm{T}-3$ treatment. Furthermore, bacterial seed inoculation significantly improved plant growth and biomass.

Likewise, to fresh biomasses, similar trend was noticed for the dry shoot and root biomasses (Table 4). Both dry shoot $(504.00 \pm 25.58 \mathrm{mg})$ and root biomasses $(88.66 \pm 3.38 \mathrm{mg})$ were recorded the highest in T-8 treatment, while the lowest values for a dry shoot $(253.00 \pm 8.38 \mathrm{mg})$ and root biomass (35.66 \pm $1.20 \mathrm{mg}$ ) was observed in T-5 and T-3 treatment, respectively (Table 4). The values recorded for dry shoot weights in T-6 and T-8 treatments were significantly compared to other treatments. The lowest dry shoot weight was recorded for T-5 (253.00 \pm 8.38 $\mathrm{mg}$ ), followed by $\mathrm{T}-4$ and T-3 treatments; however, all these 3 treatments were non-significant. In terms of percent increases over pathogen control (T-3), seeds that were sown following application of $\mathrm{CDB}$ NS-1 and CDB NS-22 showed 61.87 and $66.15 \%$ increases in dry shoot biomasses, respectively. In terms of dry root biomass, among the treatments involving the selected bacterial isolates, seeds inoculated CDB P-2 and CDB NS-22 cultures showed the lowest $(10.19 \%)$ and the highest (146.33\%) increases, respectively, over pathogen-alone treatment.

Rhizobacteria are known to increase plant growth and biomass through the mechanisms of enhanced nutrients acquisitions, iron chelation via siderophores, and plant growth hormones production and indirectly by minimizing inhibitory effect of root pathogen via niche exclusion and biological disease suppression (Backer et al. 2018). The positive influence of bioagent application on plant biometric parameters such as germination, seedlings survival and vigor index, shoot/root length, fresh/dry plant biomass, and yield have been documented (Mahmood et al. 2016).

\section{Characterization and identification of promising bacterial isolates}

The two bacterial strains showed prominent chitinolytic and antifungal activities against wilt pathogen during in vitro and green house bioassay and were characterized

Table 4 Effect of seed application with effective chitinolytic bacteria on dry biomasses of pigeon pea plants under pathogen prechallenged conditions

\begin{tabular}{|c|c|c|c|c|}
\hline \multirow[t]{2}{*}{ Treatments } & \multicolumn{4}{|c|}{ Dry plant biomasses (mg) } \\
\hline & Shoot biomasses & $\%$ changes over pathogen control & Root biomasses & $\%$ changes over pathogen control \\
\hline$\overline{\mathrm{T}-1}$ & $356.66 \pm 8.37^{\mathrm{AB}}$ & 20.22 & $49.00 \pm 2.96^{C}$ & 37.38 \\
\hline $\mathrm{T}-2$ & $407.00 \pm 13.42^{\mathrm{AB}}$ & 37.19 & $60.66 \pm 3.93^{B}$ & 70.09 \\
\hline $\mathrm{T}-3$ & $296.66 \pm 15.45^{C}$ & 0.00 & $35.66 \pm 1.20^{C}$ & 0.00 \\
\hline $\mathrm{T}-4$ & $282.33 \pm 18.12^{C}$ & -4.83 & $44.00 \pm 1.52^{c}$ & 23.36 \\
\hline $\mathrm{T}-5$ & $253.00 \pm 8.38^{C}$ & -14.72 & $39.66 \pm 5.78^{C}$ & 11.21 \\
\hline $\mathrm{T}-6$ & $491.00 \pm 32.19^{\mathrm{A}}$ & 65.51 & $73.66 \pm 5.45^{\mathrm{B}}$ & 106.54 \\
\hline $\mathrm{T}-7$ & $301.00 \pm 17.78^{C}$ & 1.46 & $46.00 \pm 5.13^{C}$ & 28.97 \\
\hline $\mathrm{T}-8$ & $504.00 \pm 25.58^{\mathrm{A}}$ & 69.89 & $88.66 \pm 3.38^{\mathrm{A}}$ & 148.60 \\
\hline
\end{tabular}

Note: Values following with the same letter are not significantly different according to DMRT test at $P \leq 0.05$ 
on the bases of phenotypic, morphological, and different biochemical tests (Table 5). The experimental studies on colony morphology and cell characteristics of both strains revealed information about their colonies morphology, margins, elevation, shape, pigmentation, grams reaction, cells shape, etc. Rhizobacterial isolate NS-1 was gram-negative, rod-shaped with single or arranged chains. Isolate NS-22 was found to be gram positive, with rod shape occurring either in single or arranged chains. Bacterial strain NS-1 was positive for all the biochemical tests except urease activity, methyl red test, and VP test. Bacterial isolate NS-22 was found positive for hydrolysis of lipid, casein, and starch, catalase activity, and citrate utilization and was negative for denitrification activity, $\mathrm{H}_{2} \mathrm{~S}$ production, TSI test, urease activity, methyl red, and VP test. Based on the 16s rDNA gene sequencing, soil CDB NS-1 was identified as Pseudomonas spp. NS-1 (NCBI GenBank accession number- KT175909) while CDB NS-22 was identified

Table 5 Phenotypic, morphological and biochemical characteristics of the selected chitinolytic and potent antifungal bacterial isolates

\begin{tabular}{|c|c|c|}
\hline Characteristics & Bacterial isolate NS-1 & Bacterial isolate NS-22 \\
\hline \multicolumn{3}{|l|}{ Isolation details } \\
\hline Place of isolation & IARI experimental field & IARI experimental field \\
\hline Crops & Pigeon pea & Pigeon pea \\
\hline Soil portion & Rhizospheric soil & Rhizospheric soil \\
\hline \multicolumn{3}{|l|}{ Colony morphology } \\
\hline Configuration & Round & Round \\
\hline Margins & Smooth & Smooth \\
\hline Elevation & Convex & Convex \\
\hline Shape & Circular & Circular \\
\hline Pigmentation & White creamy & White \\
\hline \multicolumn{3}{|l|}{ Cell morphology } \\
\hline Gram's reaction & - & + \\
\hline Shape & Rod & Rod \\
\hline Arrangement & Single & Single \\
\hline \multicolumn{3}{|l|}{ Biochemical characteristics } \\
\hline Denitrification test & + & - \\
\hline $\mathrm{H}_{2} \mathrm{~S}$ production & + & - \\
\hline Gelatin hydrolysis & + & + \\
\hline Catalase production & + & + \\
\hline Urease detection & - & - \\
\hline TSI test & + & - \\
\hline Citrate utilization test & + & + \\
\hline Methyl red test & - & - \\
\hline Voges-Proskauer test & - & - \\
\hline
\end{tabular}

Note: Data obtained in this study were expressed as positive (+) or negative (-) as Bacillus spp. NS-22 (NCBI GenBank accession number- MH425454). These gene sequences were deposited into the NCBI GenBank database.

The use of rhizosphere microflora for alleviating plants biotic and abiotic stress is a good sustainable option (Sangwan and Dukare 2018). The rhizospheric bacterial strains within the genera of Bacillus and Pseudomonas, producing a wide array of antifungal compounds, are implicated in the plant growth enhancement and biological protection against phytopathogens (Yang et al. 2020). In the present study, Pseudomonas spp. NS-1 and Bacillus spp. NS-22 were shown to produce a different chitinolytic enzymes (not published), capable of suppressing the metabolism, growth, and pathogenesis of many plant pathogenic fungi (Berini et al. 2018). Bacillus spp., known to produce resistant endospore, were the more often explored for their commercial development into viable and durable biocontrol products (Chowdhury et al. 2013). Bacillus spp. are known to produce more than 45 compounds of antimicrobial nature that mainly comprise antifungal cyclic lipopeptides (Zeriouh et al. 2014). Thus, the present study identified Bacillus spp. and Pseudomonas spp. as biocontrol agents to reduce wilt disease severity caused by $F$. udum in pigeon pea.

\section{Effect of co-inoculation of chitinolytic biocontrol bacteria on fungal biomass}

The effect of the co-inoculated bacterial cultures on pathogen mycelium dry weight $(\mathrm{mg})$ was studied after 24,48 , and $72 \mathrm{~h}$. The lowest reduction in dry weight of pathogen mycelium was observed after $24 \mathrm{~h}$ of incubation and the highest reduction was after $48 \mathrm{~h}$ of coincubation (Fig. 4). In simultaneous inoculation with Pseudomonas spp. NS-1, pathogen mycelial dry weights were $43.67,52.60$, and $59.00 \mathrm{mg}$ after 24,48 , and $72 \mathrm{~h}$ incubation, respectively, while they were $45.67,58.67$, and $67.67 \mathrm{mg}$ after 24,48 , and $72 \mathrm{~h}$ incubation, respectively, in the presence of Bacillus spp. NS-22. In terms of percentage reduction, 25.23 and $21.70 \%$ reduction in pathogen mycelium dry weight was observed at the end of 24 $\mathrm{h}$ incubation when fungi was co-inoculated with Pseudomonas spp. NS-1 and Bacillus spp. NS-22, respectively. After $72 \mathrm{~h}$ of incubation, Pseudomonas spp. NS-1 and Bacillus spp. NS-22 inoculation resulted in the decrease of mycelia dry weights by 47.58 and $42.61 \%$, respectively. Both these biocontrol strains noticeably reduced fungal mycelial biomass. Reduction in pathogen mycelial biomass is probably due to inhibition of conidial germination and/or lysis of fungal cell wall by lytic enzymes of biocontrol bacteria (Chang et al. 2007). The antagonistic activities of biocontrol bacteria by estimating the reduction in biomasses of pathogenic fungi is documented (Swain et al. 2008). 


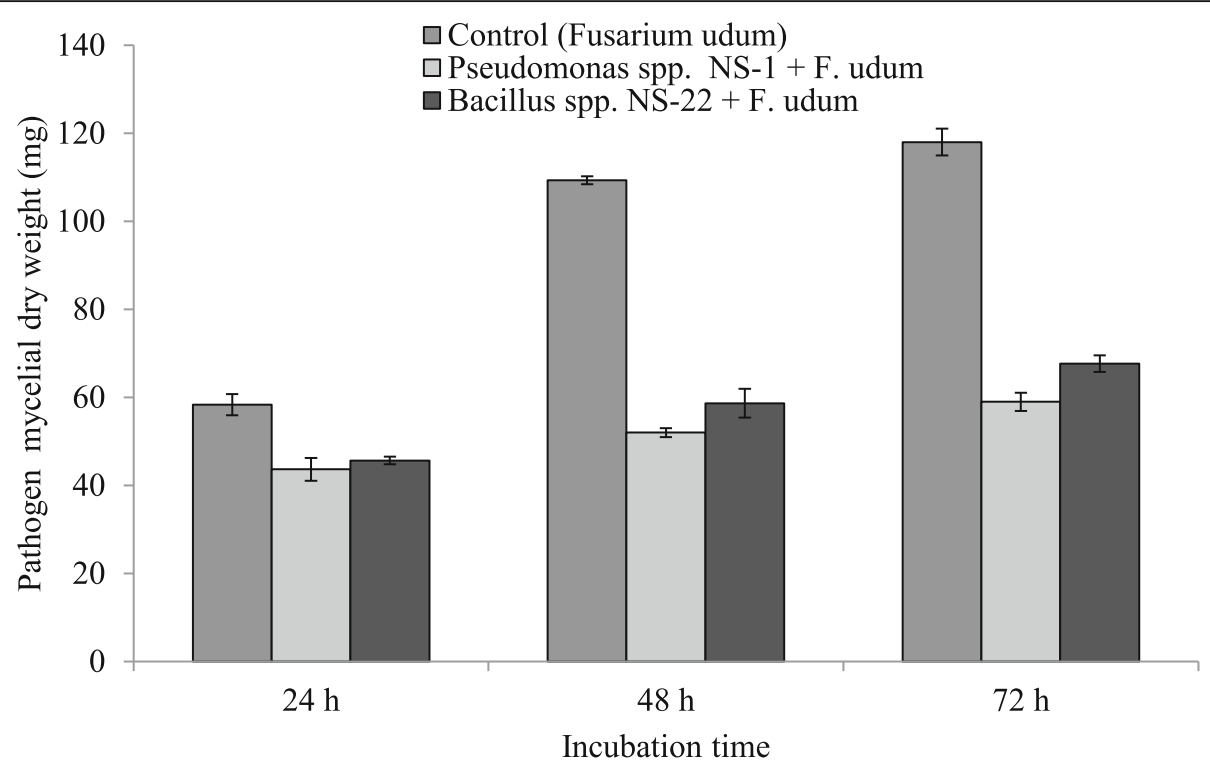

Fig. 4 Effect of chitinolytic biocontrol bacterial co-inoculation on the pathogen mycelial dry weight (mg). Values are means of three replications \pm standard errors (SE)

\section{SEM observations on the antagonistic interaction}

\section{between biocontrol bacteria and $F$. udum}

The scanning electron microscopy (SEM) studies exhibited the nature of antagonism implicated in the interaction between the isolated Pseudomonas spp. NS-1 and Bacillus spp. NS-22 with F. udum. The growth inhibitory action of bacteria on the F. udum was also evident from the mycelial disintegration and consequent damages to hyphae. Hyphal deformation with irregular cell surface morphology was also noticed at the zone of interaction between chitinolytic biocontrol bacteria and F. udum (Fig. 5). Upon treatment, bacterium Pseudomonas spp.
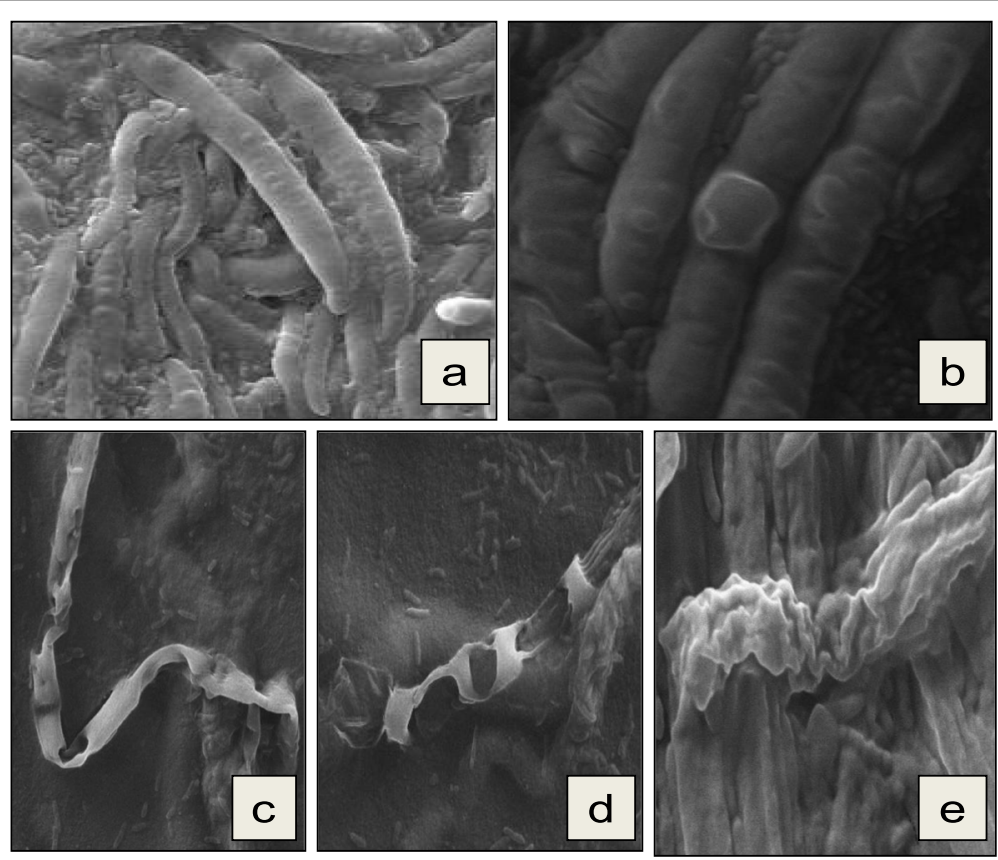

Fig. 5 Electron microscopic scanning photographs showing the antagonistic interaction between chitinolytic bacterial isolates (Pseudomonas spp. NS-1 and Bacillus spp. NS-22) with the mycelium of Fusarium udum. a Healthy mycelium as seen in untreated control. b, c Irregular shape, bulging, and lysis of pathogen mycelium caused by the bacterium Pseudomonas spp. NS-1. d, e Lysis of mycelia and mycelial distortion caused by the bacterium Bacillus spp. NS-22 
NS-1 induced various deformities including irregularities in shape and hyphal bulging, and lysis of mycelium was observed (Fig. 5b, c). Similarly, hyphal breakdown and mycelial distortion in fungi were triggered by the bacterium, Bacillus spp. NS-22. The loss of structural integrity in fungal hyphae was noticed. Further, hyper-parasitism of fungal hyphae was seen through maceration, breakdown of hyphal filaments, shrinking, shriveling, and irregular coiling (Fig. 5d, e). These results are consistent with Wang et al. (2020). The interaction between the tested bacteria on F. udum revealed that these both biocontrol strains caused an absolute mycoparasitism on the fungal hyphae. In mycoparasitism, the enzymatic collapse of pathogen hyphae induces several cellular deformities such as protoplasmic damages, lyses and mycelia distortion changes in cell membrane permeability, and outflow of cytoplasmic fluid (Di Francesco et al. 2016). Therefore, such enzymatic dissolution of the fungal wall brings protoplasmic loss that eventually causes fungal death.

\section{Conclusions}

In conclusion, Pseudomonas spp. NS-1 and Bacillus spp. NS-22 had potent chitin depolymerizing and antifungal identified in the present investigation. Briefly, strains' multiple attributes of fungal inhibition enabled them to effectively control wilt disease. Further, these strains significantly reduced wilt incidence and improved seedlings germination and plant biomass. Therefore, these strains can be used as potential bioagents for sustainable Fusarium wilt disease management and thus capable of limiting the excessive use of synthetic fungicides deployed for its wilt control.

\section{Abbreviations \\ ICAR: Indian Council of Agricultural Research; IARI: Indian Agricultural Research Institute; CDB: Chitin-degrading bacteria; CC: Colloidal chitin; NA: Nutrient agar; ITCC: Indian Type Culture Collection; PDB: Potato dextrose broth; PDA: Potato dextrose agar; CCA: Colloidal chitin agar; LB: Luria broth; SDW: Sterile distilled water; $\mathrm{H}_{2} \mathrm{~S}$ : Hydrogen sulfide; TSI: Triple sugar iron; VP: Voges-Proskauer; BLAST: Basic Local Alignment Search Tool; \\ NCBI: National Center for Biotechnology Information; SEM: Scanning electron microscopy}

\section{Acknowledgements}

The authors are thankful to the Division of Microbiology, ICAR-IARI for providing the facilities required for the present study

\section{Authors' contributions}

All authors contributed equally to the manuscript. AD participated in the planning and implementation of the experiments, sampling, lab work, writing the draft, and writing the manuscript. AA assisted in the DNA extraction, bacterial identification, and writing the manuscript. SP participated in the planning and implementation of the experiments, analyzing data, and writing the draft. AE participated in the implementation of the experiments and collection of data. All authors read and approved the final manuscript

\section{Funding}

The authors are highly thankful to the ICAR-Indian Agricultural Research Institute and Indian Council of Agricultural Research (ICAR), New Delhi, for providing financial support.

\section{Availability of data and materials}

All datasets are presented in the main manuscript.

Ethics approval and consent to participate

Not applicable.

\section{Consent for publication}

Not applicable.

\section{Competing interests}

The authors declare that they have no conflict of interest.

\section{Author details}

${ }^{1}$ Division of Horticultural Crop Processing, Indian Council of Agricultural Research (ICAR) — Central Institute of Post-Harvest Engineering \& Technology (CIPHET), Abohar, Punjab 152116, India. ²Division of Microbiology, Indian Council of Agricultural Research (ICAR)_-Indian Agricultural Research Institute (IARI), New Delhi 110012, India.

Received: 13 March 2020 Accepted: 28 April 2020

Published online: 11 May 2020

\section{References}

Aggarwal C, Paul S, Tripathi V, Paul B, Khan MA (2017) Characterization of putative virulence factors of Serratia marcescens strain SEN for pathogenesis in Spodoptera litura. J Invertebr Pathol 143. https://doi.org/10.1016/j.jip.2016. 12.004

Aggarwal C, Paul S, Tripathi V, Paul B, Khan Md A (2015) Chitinolytic activity in Serratia marcescens strain SEN and potency against different instars of Spodoptera litura Fab with effect of sub lethal doses on insect development. BioControl 60:631-640 doi: https://doi.org/10.1007/s10526-015-9674-3

Al-Fadhal FA, Al-Abedy AN, and Alkhafije DA (2019) Isolation and molecular identification of Rhizoctonia solani and Fusarium solani isolated from cucumber (Cucumis sativus L.) and their control feasibility by Pseudomonas fluorescens and Bacillus subtilis. Egypt J Biol Pest Control 29: 47 https://doi. org/10.1186/s41938-019-0145-5

Anees M, Abid M, Rehman SU, Ahmed N, Ashraf M, Zhang L, Kim KY (2019) Antifungal activity of various chitinolytic bacteria against Colletotrichum in pepper. Plant Prot Sci 55(2):109-115 https://doi.org/10.17221/72/2018-PPS

Backer R, Rokem JS, llangumaran G, Lamont J, Praslickova D, Ricci E, Subramanian S, Smith DL (2018) Plant growth-promoting rhizobacteria: context, mechanisms of action, and roadmap to commercialization of biostimulants for sustainable agriculture. Front Plant Sci 9. https://doi.org/10.3389/fpls.2018. 01473

Berini F, Katz C, Gruzdev N, Casartelli M, Tettamanti G, Marinelli F (2018) Microbial and viral chitinases attractive biopesticides for integrated pest management. Biotechnol Adv 36:818-838. https://doi.org/10.1016/j.biotechadv.2018.01.002

Cappuccino JC, Sherman N (1992) In: Microbiology: a laboratory manual, 3th ed. Benjamin/cummings Pub. Co., New York, pp. 125-179.

Chang WT, Chen YC, Jao CL (2007) Antifungal activity and enhancement of plant growth by Bacillus cereus grown on shellfish chitin wastes. Bioresour Technol 98:1224-1230 https://doi.org/10.1016/j.biortech.2006.05.005

Chowdhury SP, Dietel K, Rändler M, Schmid M, Junge H, Borriss R, Hartmann A, Grosch R (2013) Effects of Bacillus amyloliquefaciens FZB42 on lettuce growth and health under pathogen pressure and its impact on the rhizosphere bacterial community. PLoS One 8:e68818 https://doi.org/10.1371/journal. pone.0068818

Das SN, Dutta S, Kondreddy A, Chilukoti N, Pullabhotla SVSRN, Vadlamudi S, Podile AR (2010) Plant growth-promoting chitinolytic Paenibacillus elgii responds positively to tobacco root exudates. J Plant Growth Regul 29:409418 https://doi.org/10.1007/s00344-010-9152-1

Di Francesco A, Martini C, Mari M (2016) Biological control of post-harvest diseases by microbial antagonists: how many mechanisms of action.? Eur J Plant Pathol145:711-717 https://doi.org/10.1007/s10658-016-0867-0 
Dukare AS, Paul S (2018) Effect of chitinolytic biocontrol bacterial inoculation on soil microbiological activities and Fusarium population in rhizophere of Pigeon pea (Cajanus cajan). Ann Plant Protect Sci 26(1):98-103

Dukare AS, Paul S, Nambi VE, Gupta R, Sharma K, Vishwakarma RK (2019) Exploitation of microbial antagonists for the control of postharvest diseases of fruits: a review. Crit Rev Food Sci Nutr 59(9):1498-1513. https://doi.org/10. 1080/10408398.2017.1417235

Dukare AS, Prasanna R, Dubey SC, Chaudhary V, Nain L, Singh R, Saxena AK (2011) Evaluating novel microbe amended composts as biocontrol agents in tomato. Crop Prot 30:436-442. https://doi.org/10.1016/j.cropro.2010.12.017

Dukare AS, Singh RK, Jangra RK, Bhushan B (2020) Non-fungicides-based promising technologies for managing post-production penicillium induced spoilage in horticultural commodities: a comprehensive review, Food Rev Int DOI: 101080/8755912920201727497.

El-Tarabily KA (2006) Rhizosphere-competent isolates of Streptomycete and nonstreptomycete Actinomycetes capable of producing cell-wall degrading enzymes to control Pythium aphanidermatum damping-off disease of cucumber. Can J Bot 84:211-222

El-Tarabily KA, Soliman MH, Nassar AH, Al-Hassani HA, Sivasithamparam K, McKenna F, Hardy GESJ (2000) Biological control of Sclerotinia minor using a chitinolytic bacterium and Actinomycetes. Plant Pathol 49:573-583 https:// doi.org/10.1139/b05-153

FAOSTAT (2013) Available online at: www.faostat.com

Harish S, Manjula K, Podile AR (1998) Fusarium udum is resistant to the mycolytic activity of a biocontrol strain of Bacillus subtilis AF 1. FEMS Microbiol Ecol 25: 385-390 https://doi.org/10.1111/j.1574-6941.1998.tb00490.x

Howard MB, Ekborg NA, Weiner RM, Hutcheson SW (2003) Detection and characterization of chitinases and other chitin-modifying enzymes. J Ind Microbiol Biotechnol 30(11):627-635 https://doi.org/10.1007/s10295-003-0096-3

Idris HA, Labuschagne N, Korsten L (2007) Screening rhizobacteria for biological control of Fusarium root and crown rot of sorghum in Ethiopia. J Biocontrol 40:97-106 https://doi.org/10.1016/j.biocontrol.2006.07.017

Kuddus SM, Ahmad RIZ (2013) Isolation of novel chitinolytic bacteria and production optimization of extracellular chitinase. J Gen Eng Biotechnol 11: 39-46 https://doi.org/10.1016/j.jgeb.2013.03.001

Lee KY, Heo KR, Choi KH, Kong HG, Nam JS, Yi YB, Park SH, Lee SW, Moon BJ (2009) Characterization of a chitinase gene exhibiting antifungal activity from a biocontrol bacterium Bacillus licheniformis N1. Plant Pathol J 25:344-351 https://doi.org/10.5423/PPJ.2009.25.4.344

Lowry OH, Rosebrough NJ, Farr AL, Randall RJ (1951) Protein measurement with Folin phenol reagent. J Biol Chem 193:265-275

Mahmood A, Turgay OC, Farooq M, Hayat R (2016) Seed biopriming with plant growth promoting rhizobacteria: a review. FEMS Microbiol Ecol 92(8):112. https://doi.org/10.1093/femsec/fiw112

Mandal V, Sen SK, Mandal NC (2013) Production and partial characterization of an inducer dependent novel antifungal compound(s) by Pediococcus acidilactici LAB5. J Sci Food Agri https://doiorg/101002/jsfa6055

Manjula K, Podile AR (2005) Increase in seedling emergence and dry weight of pigeon pea in the field with chitin supplemented formulations of Bacillus subtilis AF 1. World J Microbiol Biotechnol 21:1057-1062. https://doi.org/10. 1007/s11274-004-8148-z

Mathivanan N (1995) Studies on extracellular chitinase and secondary metabolites produced by Fusarium chlamydosporum an antagonist to Puccinia arachidis the rust pathogen of groundnut. Ph D thesis University of Madras Chennai India

Melent'ev Al, Helisto P, Kuzmina LY, Galimzyanova NF, Aktuganov GE, Korpela T (2006) Use of antagonistic bacilli for biocontrol of fungi degrading fresh wood. Appl Biochem Microbiol 42:62-66 https://doi.org/10.1134/ S0003683806010091

Morrissey JP, Dow JM, Mark GL, O'Gara F (2004) Are microbes at the root of a solution to world food production? EMBO Rep 5(10):922-926

Naing KW, Nguyen XH, Anees M, Lee YS, Kim YC, Kim SJ, Kim MH, Kim YH, Kim KY (2015) Biocontrol of Fusarium wilt disease in tomato by Paenibacillus ehimensis KWN38. World J Microbiol Biotechnol 31:165-174. https://doi.org/ 10.1007/s11274-014-1771-4

Pandey VN, Dubey NK (1994) Antifungal potential of leaves and essential oils from higher plants against soil phytopathogens. Soil Biol Biochem 26:14171421 https://doi.org/10.1016/0038-0717(94)90226-7

Radhakrishnan R, Hashem A, Abd-Allah EF (2017) Bacillus: a biological tool for crop omprovement through bio-molecular changes in adverse environments. Front Physiol 8: 667 doi: 103389/fphys20170066
Sangwan S, Dukare AS (2018) Microbe-mediated bioremediation: an eco-friendly sustainable approach for environmental clean-up. In: Adhya TK (ed) Advances in soil microbiology recent trends and future prospects. Microorganisms for sustainability, 3rd edn. Volume 1- Soil-Microbe interaction Springer Nature, Singapore, pp 145-167 doi:https://doi.org/10. 1007/978-981-10-6178-3_8

Saraf M, Pandya U, Thakkar A (2014) Role of allelochemicals in plant growth promoting rhizobacteria for biocontrol of phytopathogens. Microbiol Res 169:1829 https://doi.org/10.1016/j.micres.2013.08.009

Sarhan MM, Ezzat SM, Tohamy MRA, El-Essawy AA, Mohamed FA (2001) Biocontrol of Fusarium tomato wilt disease by Bacillus subtilis. Egypt J Microbiol 36:376-386

Sharma M, Ghosh R, Telangre R, Rathore A, Saifulla M, Mahalinga DM, Saxena DR, Jain YK (2016) Environmental influences on Pigeonpea-Fusarium udum interactions and stability of genotypes to Fusarium wilt. Front Plant Sci 7:253. https://doi.org/10.3389/fpls.2016.00253

Swain MR, Ray RC, Nautiyal CS (2008) Biocontrol efficacy of Bacillus subtilis strains isolated from cow dung against postharvest yam (Dioscorea rotundata $\mathrm{L}$ ) pathogens. Curr Microbiol 57:407-411 https://doi.org/10.1007/s00284-0089213-x

Vaidya RJ, Macmil SLA, Vyas PR, Chhatpar HS (2003) The novel method for isolating chitinolytic bacteria and its application in screening for hyperchitinase producing mutant of Alcaligenes xylosoxydans. Lett Appl Microbiol 36:129-134 https://doi.org/10.1046/j.1472-765X.2003.01274.x

Vincent JM (1947) Distortion of fungal hyphae in the presence of certain inhibitors. Nature 150:8506

Wang S, Sun L, Zhang W et al (2020) Bacillus velezensis BM21, a potential and efficient biocontrol agent in control of corn stalk rot caused by Fusarium graminearum. Egypt J Biol Pest Control 30:9 https://doi.org/10.1186/s41938020-0209-6

Yang Y, Liu Y, Li Z, Wang Z, Li C, Wei H (2020) Significance of soil microbe in microbial-assisted phytoremediation: an effective way to enhance phytoremediation of contaminated soil. Int J Environ Sci Technol https://doi. org/10.1007/s13762-020-02668-2

Zeriouh H, de Vicente A, Pérez-García A, Romero D (2014) Surfactin triggers biofilm formation of Bacillus subtilis in melon phylloplane and contributes to the biocontrol activity. Environ Microbiol 16:2196-2211. https://doi.org/10. $1111 / 1462-2920.12271$

\section{Publisher's Note}

Springer Nature remains neutral with regard to jurisdictional claims in published maps and institutional affiliations.

\section{Submit your manuscript to a SpringerOpen ${ }^{\circ}$ journal and benefit from:}

- Convenient online submission

- Rigorous peer review

- Open access: articles freely available online

- High visibility within the field

- Retaining the copyright to your article

Submit your next manuscript at $>$ springeropen.com 